\title{
Functional Adenylyl Cyclase Inhibition in Murine Cardiomyocytes by $2^{\prime}\left(3^{\prime}\right)-O-(N-$ Methylanthraniloyl)-Guanosine $5^{\prime}-\left[\gamma^{-}\right.$-Thio]triphosphate
}

\author{
Dennis Rottlaender, Jan Matthes, Stephen F. Vatner, Roland Seifert, and Stefan Herzig \\ Department of Pharmacology (D.R., J.M., S.H.) and Center for Molecular Medicine (S.H.), University of Cologne, Köln, \\ Germany; Department of Cell Biology and Molecular Medicine, Cardiovascular Research Institute, University of Medicine and \\ Dentistry of New Jersey, New Jersey Medical School, Newark, New Jersey (S.F.V.); and Department of Pharmacology and \\ Toxicology, University of Regensburg, Regensburg, Germany (R.S.)
}

Received December 11, 2006; accepted February 2, 2007

\begin{abstract}
$\beta_{1}$-Adrenergic receptor activation stimulates cardiac L-type $\mathrm{Ca}^{2+}$ channels via adenylyl cyclases (ACs), with AC5 and AC6 being the most important cardiac isoforms. Recently, we have identified 2'(3')-O-(N-methylanthraniloyl)-guanosine 5'-[ $\gamma$-thiotriphosphate (MANT-GTP $\gamma \mathrm{S}$ ) as a potent competitive AC inhibitor. Intriguingly, MANT-GTP $\gamma$ S inhibits AC5 and -6 more potently than other cyclases. These data prompted us to study the effects of MANT-GTP $\gamma \mathrm{S}$ on L-type $\mathrm{Ca}^{2+}$ currents $\left(\mathrm{I}_{\mathrm{Ca}, \mathrm{L}}\right)$ in ventricular myocytes of wild-type (WT) and AC5-deficient $\left(\mathrm{AC}^{-/-}\right.$) mice by whole-cell recordings. In wild-type myocytes, MANT-GTP $\gamma \mathrm{S}$ attenuated $\mathrm{I}_{\mathrm{Ca}, \mathrm{L}}$ stimulation following isoproterenol application in a concentration-dependent manner (control, $+77 \pm 13 \%$; 100 nM MANT-GTP $\gamma \mathrm{S},+43 \pm 6 \%$; $1 \mu \mathrm{M}$ MANTGTP $\gamma \mathrm{S},+21 \pm 9 \% ; p<0.05)$. The leftward shift of current-
\end{abstract}

voltage curves was abolished by $1 \mu \mathrm{M}$ but not by $100 \mathrm{nM}$ MANT-GTP $\gamma$ S. In myocytes from $\mathrm{AC5}^{-1-}$ mice, the residual stimulation of $\mathrm{I}_{\mathrm{Ca}, \mathrm{L}}$ was not further attenuated by the nucleotide, indicating AC5 to be the major AC isoform mediating acute $\beta$-adrenergic stimulation in WT mice. Interestingly, basal $\mathrm{I}_{\mathrm{Ca}, \mathrm{L}}$ was lowered by $1 \mu \mathrm{M}$ but not by $100 \mathrm{nM}$ MANT-GTP $\gamma \mathrm{S}$. The decrease was less pronounced in myocytes from $A C 5^{-1-}$ mice compared with wild types ( $-23 \pm 1$ versus $-40 \pm 7 \%$ ), indicating basal $\mathrm{I}_{\mathrm{Ca}, \mathrm{L}}$ to be partly driven by AC5. Collectively, we found $\mathrm{a}$ concentration-dependent inhibition of $\mathrm{I}_{\mathrm{Ca}, \mathrm{L}}$ by MANT-GTP $\gamma \mathrm{S}$, both under basal conditions and following $\beta$-adrenergic stimulation. Comparison of data from wild-type and AC5-deficient mice indicates that $A C 5$ plays a major role in $\mathrm{I}_{\mathrm{Ca}, \mathrm{L}}$ activation and that MANT-GTP $\gamma S$ predominantly acts via AC5 inhibition.
$\beta_{1}$-Adrenoreceptor activation via the stimulatory $\mathrm{G}$ protein $\mathrm{G} \alpha_{\mathrm{S}}$ leads to enhanced cAMP generation catalyzed by adenylyl cyclases (ACs). cAMP mediates diverse cellular responses, e.g., by activating protein kinase A. One target for phosphorylation by protein kinase $\mathrm{A}$ is the cardiac L-type $\mathrm{Ca}^{2+}$ channel (Kamp and Hell, 2000). At least 10 mammalian AC isoforms with a tissue-specific distribution have been identified (Hanoune and Defer, 2001). In mammalian heart the $\mathrm{Ca}^{2+}$ dependent isoforms AC5 and AC6 are the two main cyclase isoforms at the mRNA level. Besides AC5 and AC6, several other AC isoforms (types 2, 3, 4, 7, and 9) were found in murine hearts (Okumura et al., 2003a), but they are thought

This work was supported by Deutsche Forschungsgemeinschaft Grant Se 529/5-1 (to R.S.), National Institutes of Health Grants HL069020, AG023137, AG028854, AG014121, HL033107, HL59139, and HL069752 (to S.F.V.), KölnFortune KF 186/2004 (to S.H.), and Zentrum für Molekulare Medizin der Universität zu Köln A5 (to S.H.).

Article, publication date, and citation information can be found at http://jpet.aspetjournals.org.

doi:10.1124/jpet.106.118422. to play a negligible functional role due to low expression levels or low enzymatic activity (Defer et al., 2000; Hanoune and Defer, 2001).

Although AC5 represents the isoform with the highest catalytic activity in the adult heart (Ishikawa et al., 1992), it remains unclear whether it is the functionally dominant cardiac isoform, in particular regarding acute regulation of L-type $\mathrm{Ca}^{2+}$ channel activity and thus modulation of $\mathrm{Ca}^{2+}$ influx triggering contraction. Nevertheless, AC5 is an interesting potential drug target in the therapy of heart disease. In this regard, transgenic overexpression of type $6 \mathrm{AC}$ did not induce abnormal histological findings or deleterious changes in the heart (Gao et al., 1999), whereas overexpression of type 5 AC affects basal AC activity and cardiac function (Tepe et al., 1999). These findings indicate that AC5, in contrast to type $6 \mathrm{AC}$, plays an important role under pathological conditions. Furthermore in AC5-knockout (AC5 ${ }^{-/-}$) mice, contractile properties and L-type $\mathrm{Ca}^{2+}$ currents $\left(\mathrm{I}_{\mathrm{Ca}, \mathrm{L}}\right)$ were impaired in a $\mathrm{Ca}^{2+}$-dependent manner (Okumura et al.,

ABBREVIATIONS: AC, adenylyl cyclase; I $\mathrm{Ca}_{\mathrm{L}}$, L-type calcium current; MANT, $2^{\prime}\left(3^{\prime}\right)-\mathrm{O}-\left(\mathrm{N}\right.$-methylanthraniloyl); GTP $\gamma \mathrm{S}$, guanosine $5^{\prime}$-[ $\gamma$-thio]triphosphate; WT, wild-type; I/V, current-voltage. 
2003a), whereas cardiac function was protected against pressure overload induced by aortic banding (Okumura et al., 2003b). Particularly, these findings on AC5 deficiency underline the important role of AC5 in murine hearts and suggest $\mathrm{AC}$ inhibitors to be promising pharmacological tools and perhaps even therapeutics. This notion is supported by the finding that excessive activation of the $\beta_{1}$-adrenoreceptor$\mathrm{G} \alpha_{\mathrm{S}}$-AC cascade is detrimental for cardiac function (Engelhardt et al., 1999; Lohse et al., 2003).

Most AC inhibitors known so far are either noncompetitive or nonspecific regarding isoforms (Hanoune and Defer, 2001; Iwatsubo et al., 2004). However, with respect to therapeutic use, both competitiveness and isoform specificity would be helpful properties in minimizing the risk of adverse effects. Recently, we have identified $2^{\prime}\left(3^{\prime}\right)-O$-( $N$-methylanthraniloyl $)$ (MANT) nucleotides as a novel class of potent competitive AC inhibitors (Gille and Seifert, 2003). Intriguingly, MANT-nucleotides inhibit AC5 and AC6 more potently than other cyclases (Gille et al., 2004). Crystallographic, biophysical, and biochemical studies have provided in-depth insight into the molecular interactions of MANT-nucleotides with AC, providing a rational basis for the development of even more potent and selective AC inhibitors than those currently available (Mou et al., 2005, 2006).

To assess the pharmacological effects of MANT nucleotides in murine cardiomyocytes, we took advantage of the pivotal position of AC linking $\beta$-adrenergic signaling to L-type $\mathrm{Ca}^{2+}$ current stimulation. We used the hydrolysis-resistant MANT-nucleotide MANT-GTP $\gamma \mathrm{S}$ (Fig. 1) as a prototypical competitive AC inhibitor. During whole-cell patch-clamp recordings, the membrane-impermeant compound was delivered by intracellular dialysis. Freshly isolated murine cardiomyocytes were exposed to isoproterenol to study AC5 inhibition under basal conditions and $\beta$-adrenergic stimulation. We repeated these experiments in $\mathrm{AC} 5^{-\prime-}$ cardiomyocytes to determine the AC5 specificity of the effects of MANTGTP $\gamma \mathrm{S}$.

\section{Materials and Methods}

Animals. Mice (3-9 months old) with type 5 adenylyl cyclase deficiency (AC5 ${ }^{-1-}$ ) (Okumura et al., 2003b) were fully backcrossed (more than five generations) into the C57/Bl6 strain and bred with their respective nontransgenic littermates. Wild-type C57/B16 mice (3-9 months old) served as control. Experiments complied with respective laws and local regulations regarding animal care.

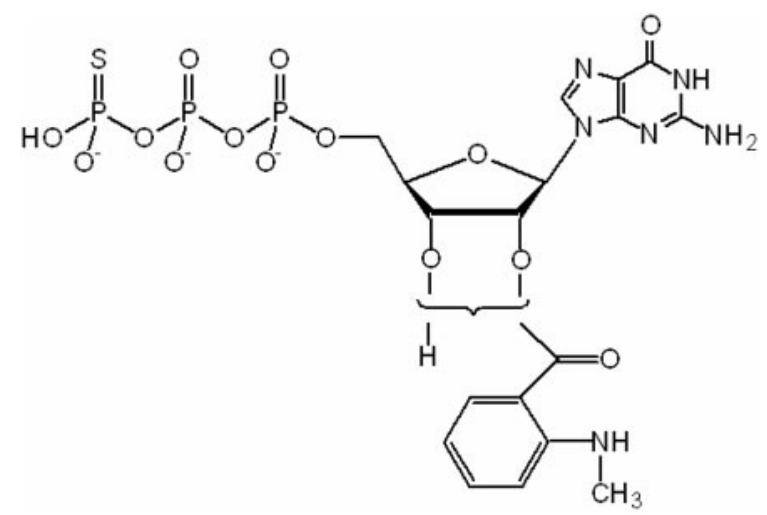

Fig. 1. Structural formula of MANT-GTP $\gamma \mathrm{S}$. Note the spontaneous isomerization between the 2 - and $3^{\prime}$-MANT-substituted structure.
Genotyping of Knockout Mice. A tail-clip analysis was performed at 3 to 4 weeks of age. After preparation of genomic DNA, a polymerase chain reaction was run. To genotype $\mathrm{AC} 5^{-1-}$, we used the following primer pairs: wild type $(+)$, forward, $5^{\prime}$-CGC TAC TTC TTC CAC CTG AAC CAG-3'; reverse, 5'-TGA TAA GGA TCA CGC CCA CAG C-3', and knockout (-), forward, 5'-TCG TGC TTT ACG GTA TCG CCG CTC CCG ATT-3'; reverse, 5'-TGA TAA GGA TCA CGC CCA CAG C-3'. Both reactions were run over 40 cycles (saturation). Amplified sequences were 157 base pairs for the WT allele and 443 base pairs for the targeting construct.

Isolation of Cardiac Myocytes. Single ventricular myocytes were isolated by enzymatic dissociation using the method described previously (Foerster et al., 2003). In brief, hearts were perfused with a collagenase solution (Worthington type I and II, $75 \mathrm{U} / \mathrm{ml}$; Cell Systems, St. Katharinen, Germany) in a Langendorff setup, and they were subsequently cut into small chunks. Myocytes were harvested by pouring the suspension through cheesecloth.

Whole-Cell Recording. L-type calcium channel currents were measured at room temperature using the whole-cell configuration of the patch-clamp technique as described previously (Heubach et al., 2001). Whole-cell experiments were performed in an external solution containing $137 \mathrm{mM} \mathrm{NaCl}, 5.4 \mathrm{mM} \mathrm{CsCl}, 2 \mathrm{mM} \mathrm{CaCl}_{2}, 1.25 \mathrm{mM}$
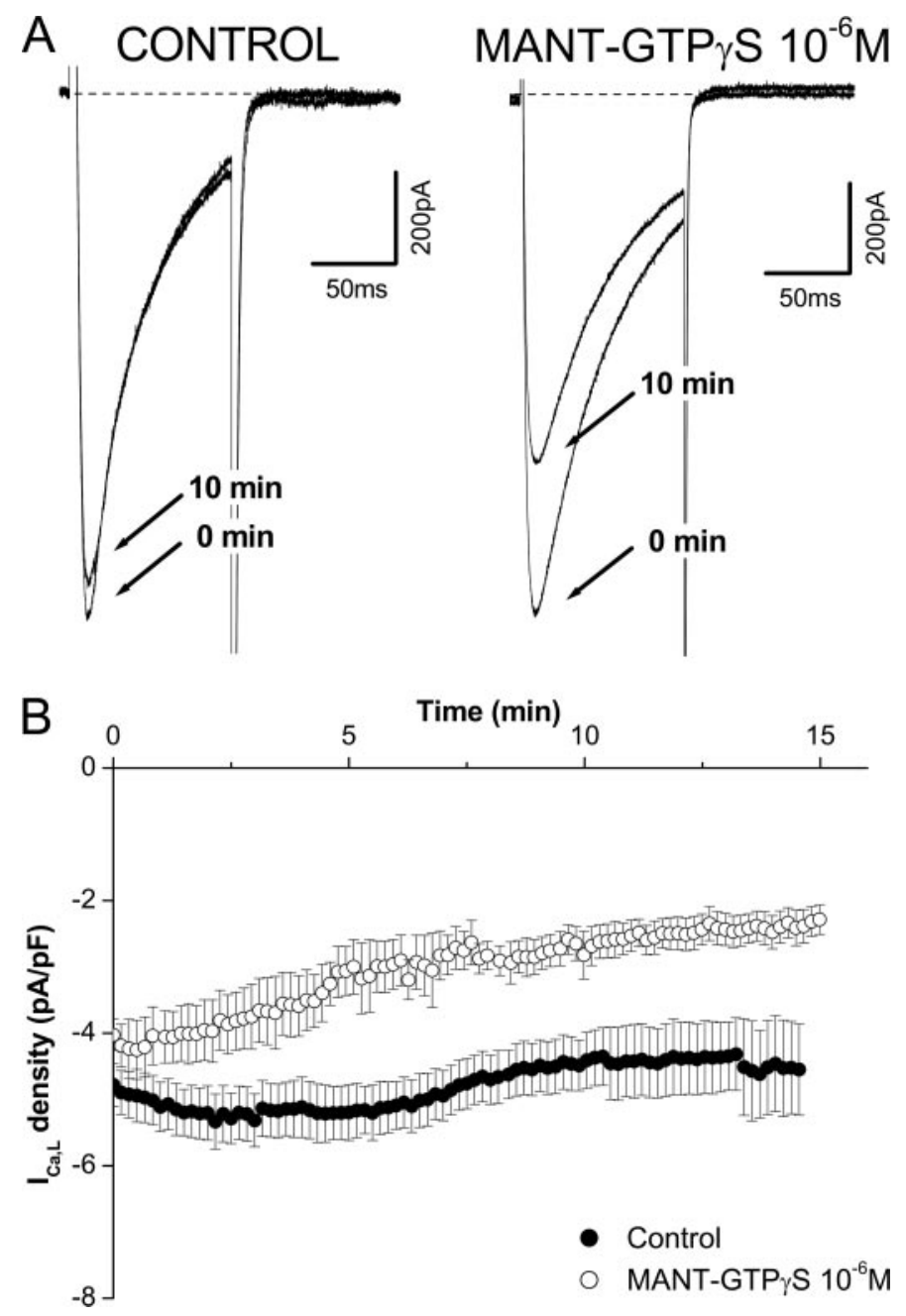

Fig. 2. Effect of $1 \mu \mathrm{M}$ MANT-GTP $\gamma \mathrm{S}$ on basal L-type $\mathrm{Ca}^{2+}$ current in wild-type murine cardiomyocytes. A, original traces in the absence and presence of $1 \mu \mathrm{M}$ MANT-GTP $\gamma \mathrm{S}$ at the time points 0 and $10 \mathrm{~min}$. B, averaged time course of whole-cell L-type $\mathrm{Ca}^{2+}$ current density in the absence (filled symbols; $n=6$ ) and in the presence of $1 \mu \mathrm{M}$ MANT-GTP $\gamma \mathrm{S}$ (open symbols; $n=6$ ). Starting from a holding potential of $-60 \mathrm{mV}$ the current was elicited by a test potential of $+10 \mathrm{mV}$ preceded by a prepulse to $-40 \mathrm{mV}$. 
A CONTROL

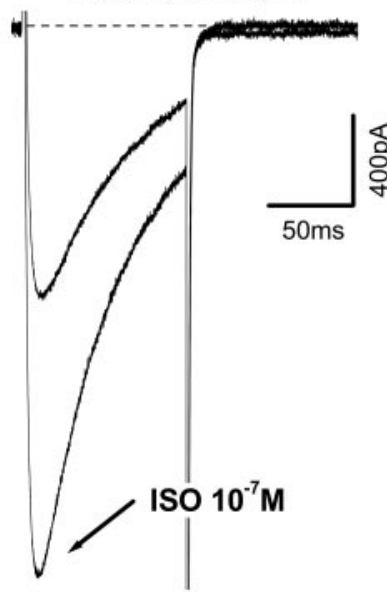

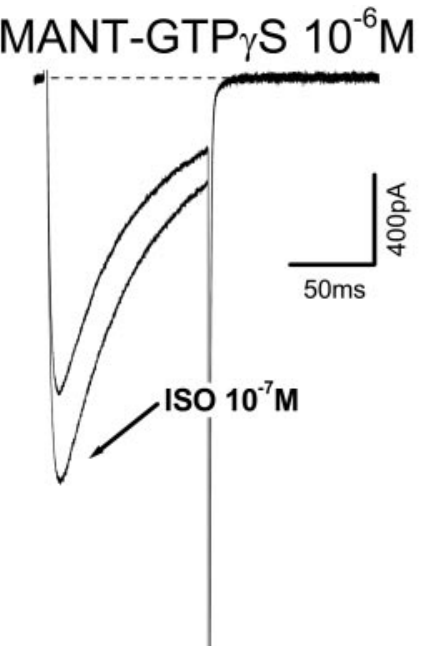

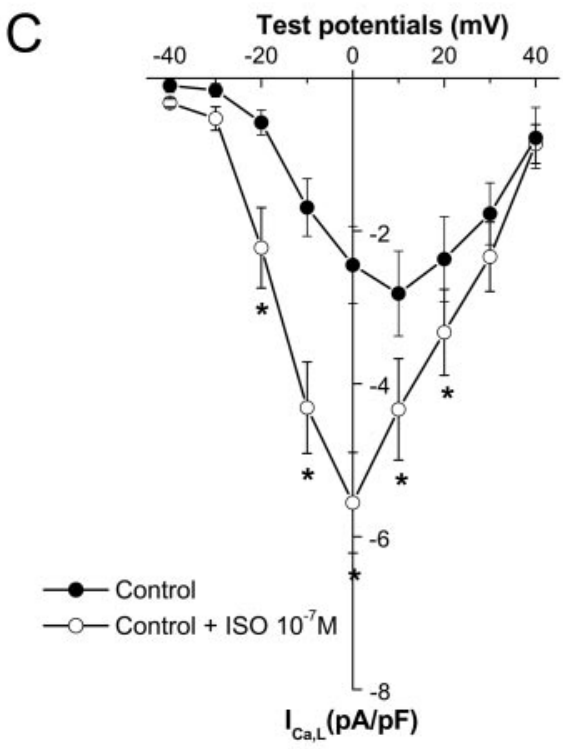

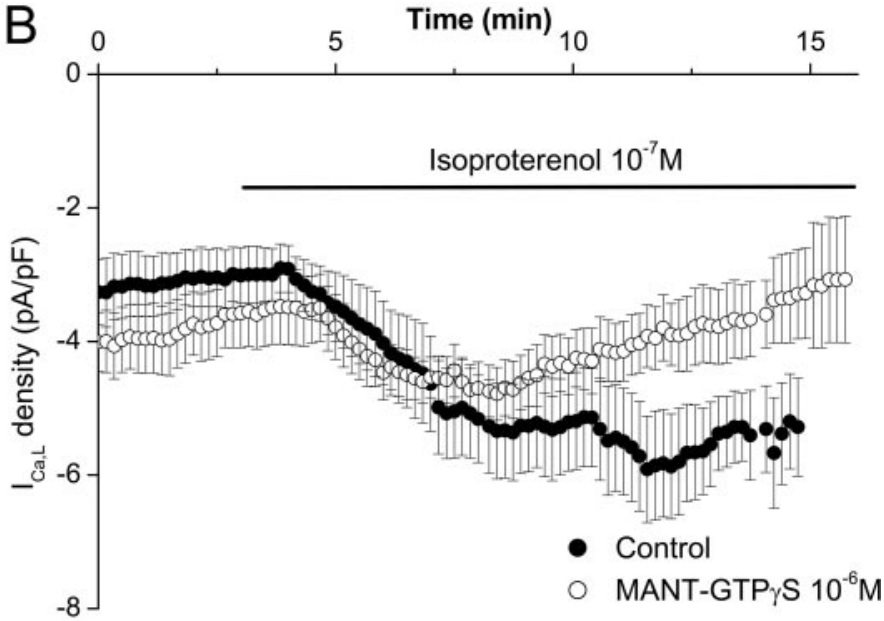

$\mathrm{D}$

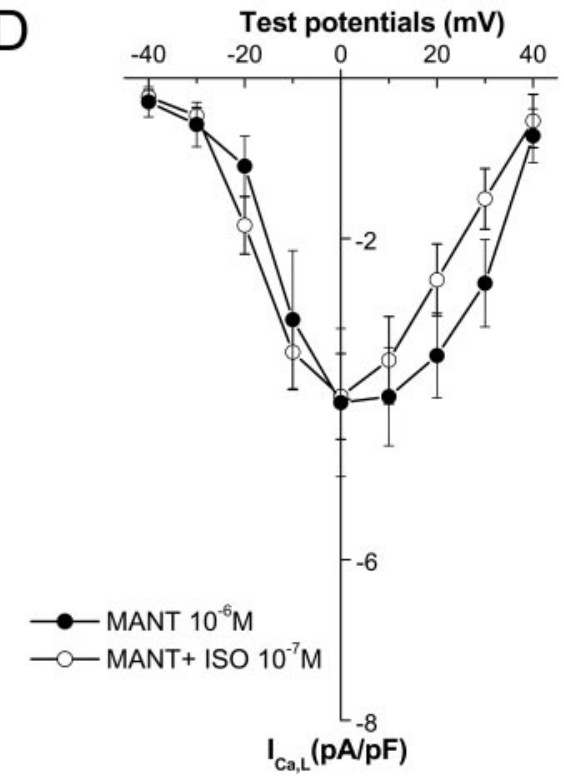

Fig. 3. Effect of $1 \mu \mathrm{M}$ MANT-GTP $\gamma \mathrm{S}$ on isoproterenol-stimulated L-type $\mathrm{Ca}^{2+}$ current in wild-type murine cardiomyocytes. Cells were superfused by isoproterenol containing bath solution for $12.0 \pm 0.1 \mathrm{~min}$ (control) and $13.0 \pm 0.2 \mathrm{~min}$ (MANT-GTP $\gamma \mathrm{S}$ ), respectively. A, original traces before and after $100 \mathrm{nM}(-)$-isoproterenol stimulation and in the absence and presence of $1 \mu \mathrm{M}$ MANT-GTP $\gamma \mathrm{S}$ at the time point 0 min and at the maximal increase of L-type $\mathrm{Ca}^{2+}$ current. B, averaged time course of whole-cell L-type $\mathrm{Ca}^{2+}$ current density from experiments with murine ventricular myocytes before and after $100 \mathrm{nM}(-$ )-isoproterenol stimulation and in the absence (filled symbols; $n=5$ ) and in the presence of $1 \mu \mathrm{M}$ MANT-GTP $\gamma \mathrm{S}$ (open symbols; $n=5$ ). Starting from a holding potential of $-60 \mathrm{mV}$, the current was elicited by a test potential of $+10 \mathrm{mV}$ preceded by a prepulse to $-40 \mathrm{mV}$. C, control current density-voltage relationship in the absence (filled symbols; $n=5$ ) and in the presence (open symbols; $n=5$ ) of $100 \mathrm{nM}(-$ )-isoproterenol, measured before and $10 \mathrm{~min}$ after start of isoproterenol application. D, current density-voltage relationship with $1 \mu \mathrm{M}$ MANT-GTP $\gamma \mathrm{S}$ diluted in the pipette solution in the absence (filled symbols; $n=5$ ) and in the presence (open symbols; $n=5$ ) of $100 \mathrm{nM}(-$ )-isoproterenol measured at the beginning and at the end of the experiments. $*, p<0.05$ (alternate $t$ test).

$\mathrm{MgCl}_{2}, 10 \mathrm{mM}$ HEPES, and $10 \mathrm{mM}$ glucose, $\mathrm{pH} 7.4$ with $\mathrm{NaOH}$. Pipettes (1.5 to $3-\mathrm{M} \Omega$ borosilicate glass) were filled with $140 \mathrm{mM}$ $\mathrm{CsCl}, 4 \mathrm{mM} \mathrm{MgCl}_{2}, 10 \mathrm{mM}$ HEPES, $10 \mathrm{mM}$ EGTA, and $4 \mathrm{mM}$ $\mathrm{Na}_{2} \mathrm{ATP}, \mathrm{pH} 7.3$ with $\mathrm{CsOH}$. Cells were continuously superfused with drug-free bath solution, and then they were switched to a solution containing $100 \mathrm{nM}$ (-)-isoproterenol. Gigaohm seals were formed by gentle suction. The seal resistances were usually between 2 and 5 G $\Omega$. Before series resistance compensation, membrane capacitance was measured by means of fast depolarizing ramp pulses (from -40 to $-35 \mathrm{mV} ; 5-\mathrm{ms}$ duration) at the beginning of each experiment. Compensated access resistance was regularly checked and maintained below $5 \mathrm{M} \Omega$. Series resistance was routinely compensated by 50 to $70 \%$. Membrane currents were low-pass filtered at $2 \mathrm{kHz}$. Only rod-shaped myocytes with clear striation were used. Whole-cell $\mathrm{Ca}^{2+}$ currents were elicited by $200-\mathrm{ms}$ depolarizing voltage steps from a holding potential of $-60 \mathrm{mV}$. The stimulation frequency was $0.2 \mathrm{~Hz}$ (EPC-9; HEKA, Lambrecht/Pfalz, Germany). For each cell, a current-voltage relationship was established at the beginning and the end of the experiment. The test potential was +10 $\mathrm{mV}$. For isolation of $\mathrm{I}_{\mathrm{Ca}, \mathrm{L}}$ from contaminating currents, sodium and T-type calcium currents were inactivated by a 50-ms-long prepulse to $-40 \mathrm{mV}$ (holding potential $-60 \mathrm{mV}$ ), and $\mathrm{K}^{+}$currents were minimized by replacing $\mathrm{K}^{+}$with $\mathrm{Cs}^{+}$. To account for variability in cell size, absolute current amplitudes [in picoamperes (pA)] were divided by the respective cell capacitance [in picofarads $(\mathrm{pF})$ ], and values are expressed as membrane current I in picoamperes per picofarads. The software PULSE, version 9.12 (HEKA) was used for data acquisition.

Drugs. MANT-GTP $\gamma \mathrm{S}$ (Jena Bioscience, Jena, Germany) and (-)isoproterenol HCl (Sigma Chemie, Deisenhofen, Germany) were prepared as $10 \mathrm{mM}$ stock solutions in double-distilled $\mathrm{H}_{2} \mathrm{O}$. Isoproterenol was further diluted in bath solution and superfused the cardiomyocytes using a rapid solution changer (RSC 200; Bio-Logic, 
Claix, France). MANT-GTP $\gamma \mathrm{S}$ was diluted in pipette solution immediately before use.

Statistics and Data Analysis. Results are given as mean values \pm S.E.M. Differences between mean values were tested by alternate $t$ test and considered statistically significant for $p<0.05$.

\section{Results}

Effect of MANT-GTP $\gamma \mathbf{S}$ on Basal $I_{\mathrm{Ca}, \mathrm{L}}$ in Wild-Type Myocytes. We first wanted to assess the effect of MANTGTP $\gamma \mathrm{S}$ on basal currents mediated by L-type $\mathrm{Ca}^{2+}$ channels in wild-type ventricular myocytes. Under control conditions, $\mathrm{I}_{\mathrm{Ca}, \mathrm{L}}$ showed a slight decrease that did not exceed $8 \%$ of the initial current within $10 \mathrm{~min}$, and it reached stable values for the remaining recording time (from $-4.8 \pm 0.3 \mathrm{pA} / \mathrm{pF}$ to $-4.4 \pm 0.25 \mathrm{pA} / \mathrm{pF}$ after $10 \mathrm{~min}$; N.S., $n=6$; Fig. $2 \mathrm{~B}$ ). When $1 \mu \mathrm{M}$ MANT-GTP $\gamma \mathrm{S}$ was present in the pipette solution, current density was not instantaneously different compared with control recordings, but it decreased significantly over time (Fig. 2, A and B). After 10 min of recording with MANTGTP $\gamma \mathrm{S}$ in the pipette, current density was lowered by $40 \pm 7 \%$ (Fig. $2, \mathrm{~A}$ and $\mathrm{B}$; from $-4.0 \pm 0.24 \mathrm{pA} / \mathrm{pF}$ to $-2.5 \pm 0.3 \mathrm{pA} / \mathrm{pF}$; $p<0.05, n=6$ ). This demonstrates that $1 \mu \mathrm{M}$ MANT-GTP $\gamma \mathrm{S}$ reduced basal L-type $\mathrm{Ca}^{2+}$ current as a function of time, due to intracellular dialysis via the patch pipette. The reduction of basal L-type $\mathrm{Ca}^{2+}$ channel activity reached a plateau after 12 to 15 min of recording, suggesting that the reduction of L-type $\mathrm{Ca}^{2+}$ current is not due to continuous "run-down."

Effects of MANT-GTP $\gamma \mathbf{S}$ on $I_{\mathrm{Ca}, \mathrm{L}}$ Stimulation by Isoproterenol in Wild-Type Myocytes. Isoproterenol is known to stimulate currents mediated by L-type $\mathrm{Ca}^{2+}$ channels due to increased protein kinase A activity following enhanced cAMP production catalyzed by AC. We therefore obtained $\mathrm{I}_{\mathrm{Ca}, \mathrm{L}}$ stimulated by isoproterenol in the absence and the presence of the AC inhibitor MANT-GTP $\gamma \mathrm{S}$ at $1 \mu \mathrm{M}$. Under control conditions, $100 \mathrm{nM}$ isoproterenol increased maximal $\mathrm{I}_{\mathrm{Ca}, \mathrm{L}}$ by $77 \%$. This increase was attenuated to only $+21 \%$ in the presence of MANT-GTP $\gamma \mathrm{S}(+77 \pm 13$ versus $+21 \pm 9 \% ; p<0.01, n=10$; Figs. $3, \mathrm{~A}$ and $\mathrm{B}$, and $5 \mathrm{D}$ ). When MANT-GTP $\gamma \mathrm{S}$ was applied, the leftward-shift of I/V curves typically caused by isoproterenol was absent (Fig. 3, C and D). It is noteworthy that after $15 \mathrm{~min}$ of isoproterenol perfusion, currents still were significantly increased above predrug values in the absence of MANT-GTP $\gamma \mathrm{S}$. In contrast, in the presence of the $\mathrm{AC}$ inhibitor, current density declined below values obtained before drug application (Fig. 3B). This could be due to an ongoing reduction of basal current, of isoproterenol-stimulated current, or both. To discriminate between these possibilities, washout experiments were performed. Isoproterenol was applied early in the course of the experiment and washed out 10 min later (Fig. 4, A and B). Compared with controls (Fig. 4B), calcium current decrease by isoproterenol washout was less pronounced in the presence of MANT-GTP $\gamma \mathrm{S}$, indicating smaller remaining agonist effect at that time. These data match our findings showing a decrease in current density by MANT-GTP $\gamma \mathrm{S}$ even in the absence of $\beta$-adrenergic stimulation (see above). In summary, MANT-GTP $\gamma$ S significantly and almost completely diminished the increase of $\mathrm{I}_{\mathrm{Ca}, \mathrm{L}}$ due to isoproterenol.

Concentration Dependence of MANT-GTP $\gamma \mathrm{S}$ Effects on $\mathbf{I}_{\mathbf{C a}, \mathbf{L}}$ in Wild-Type Myocytes. MANT-GTP $\gamma \mathrm{S}$ inhibited isoproterenol effects in a concentration-dependent way. A

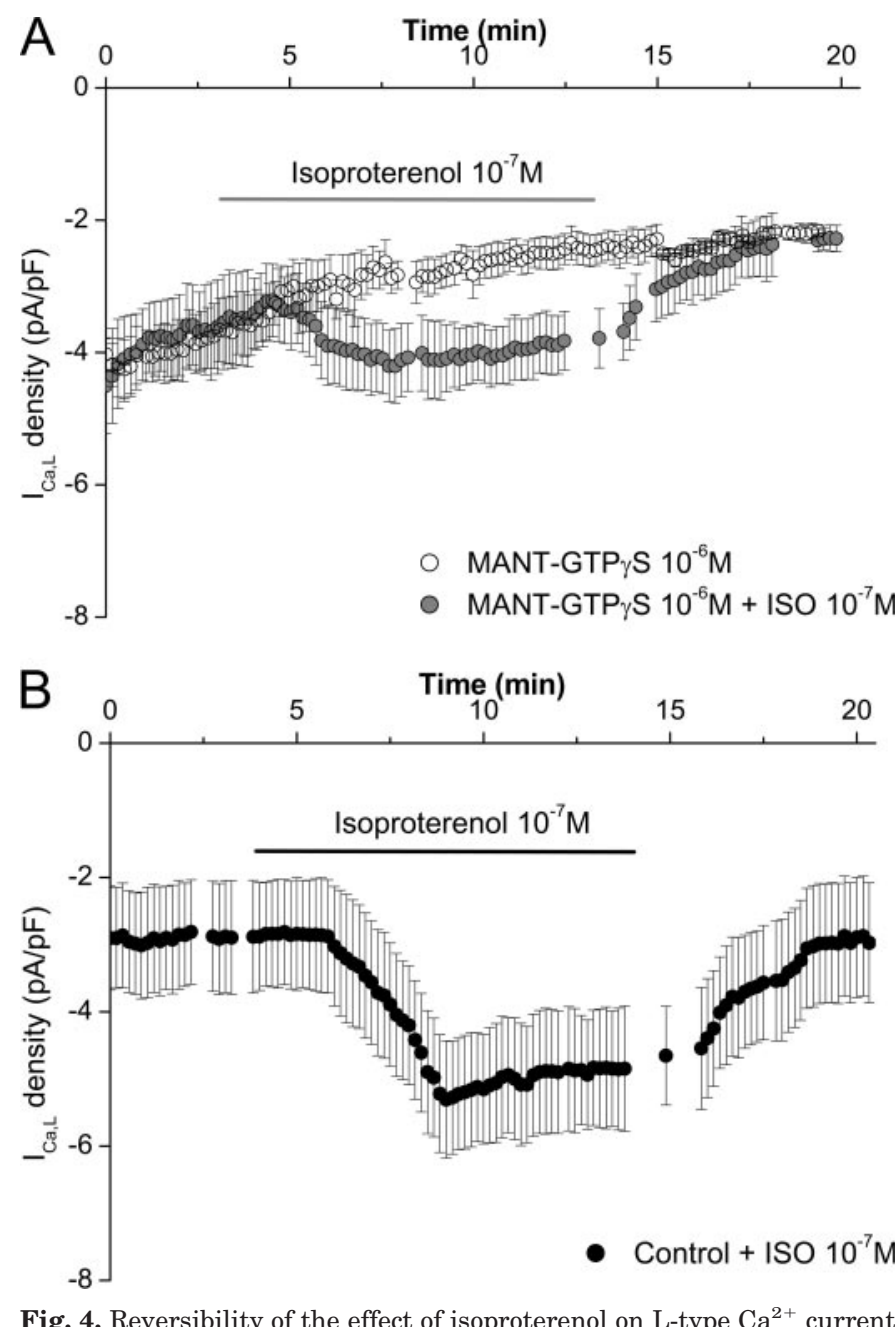

Fig. 4. Reversibility of the effect of isoproterenol on L-type $\mathrm{Ca}^{2+}$ current in wild-type murine cardiomyocytes. A, averaged time course of wholecell L-type $\mathrm{Ca}^{2+}$ current density from experiments with myocytes before and after $100 \mathrm{nM}$ (-)-isoproterenol stimulation, followed by isoproterenol washout in the presence of $1 \mu \mathrm{M}$ MANT-GTP $\gamma \mathrm{S}$ (filled symbols; $n=5$ ). Open symbols show basal L-type $\mathrm{Ca}^{2+}$ current time course (cf. Fig. 2B) to illustrate reversibility of isoproterenol stimulation in the presence of MANT-GTP $\gamma \mathrm{S}$. Starting from a holding potential of $-60 \mathrm{mV}$ the current was elicited by a test potential of $+10 \mathrm{mV}$ preceded by a prepulse to -40 $\mathrm{mV}$. B, filled symbols represent the averaged $(n=5)$ time course of similar washout experiments, performed in the absence of MANTGTP $\gamma \mathrm{S}$.

lower concentration of the MANT-nucleotide, $100 \mathrm{nM}$, still reduced the increase in $\mathrm{I}_{\mathrm{Ca}, \mathrm{L}}$ due to $100 \mathrm{nM}$ isoproterenol stimulation (Fig. 5A), albeit to a lower extent (control, $+77 \pm$ $13 \%$; $100 \mathrm{nM}$ MANT-GTP $\gamma \mathrm{S},+43 \pm 6 \%$; and $1 \mu \mathrm{M}$ MANTGTP $\gamma \mathrm{S},+21 \pm 9 \%$; Fig. 5D). It is noteworthy that in the presence of the lower MANT-GTP $\gamma \mathrm{S}$ concentration, isoproterenol still caused the typical leftward shift of the I/V curve as observed under control conditions (Fig. 5C). Interestingly, 8 min after starting $100 \mathrm{nM}$ isoproterenol perfusion, stimulated $\mathrm{I}_{\mathrm{Ca}, \mathrm{L}}$ remained stable in the presence of $100 \mathrm{nM}$ MANTGTP $\gamma \mathrm{S}$, suggesting that no further decrement of the isoproterenol effect was caused by the low nucleotide concentration (Fig. 5, A and B). These findings also suggest that lower concentrations of the nucleotide did not affect basal $\mathrm{I}_{\mathrm{Ca}, \mathrm{L}}$. To evaluate the effect of $100 \mathrm{nM}$ MANT-GTP $\gamma \mathrm{S}$ on basal $\mathrm{I}_{\mathrm{Ca}, \mathrm{L}}$, a comparison of current values immediately before starting isoproterenol perfusion (at $2.5 \mathrm{~min}$ ) was performed. Under control conditions $(+4 \pm 2 \%)$ and in the presence of $100 \mathrm{nM}$ 

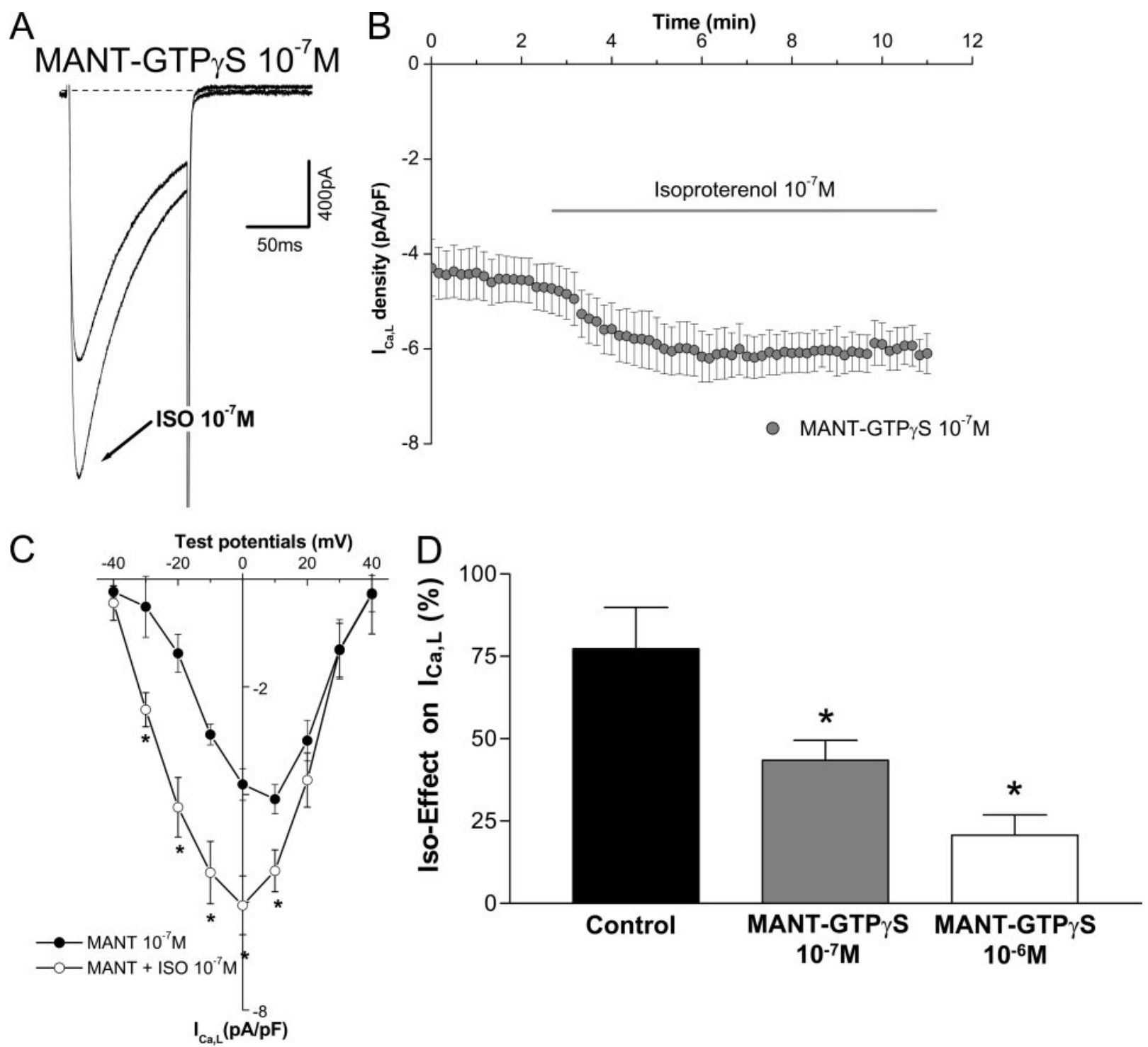

Fig. 5. Effect of $100 \mathrm{nM}$ MANT-GTP $\gamma \mathrm{S}$ on isoproterenol-stimulated L-type $\mathrm{Ca}^{2+}$ current in wild-type murine cardiomyocytes. Cells were superfused by isoproterenol containing bath solution for $8.4 \pm 0.1 \mathrm{~min}$. A, original traces before and after $100 \mathrm{nM}(-)$-isoproterenol stimulation and in the presence of $100 \mathrm{nM}$ MANT-GTP $\gamma \mathrm{S}$ at the time point $0 \mathrm{~min}$ and at the maximal increase of L-type $\mathrm{Ca}^{2+}$ current. B, averaged time course of whole-cell L-type $\mathrm{Ca}^{2+}$ current density from experiments with murine ventricular myocytes before and after $100 \mathrm{nM}(-)$-isoproterenol stimulation in presence of 100 nM MANT-GTP $\gamma \mathrm{S}$ (filled symbols; $n=5$ ). Starting from a holding potential of $-60 \mathrm{mV}$, the current was elicited by a test potential of $+10 \mathrm{mV}$ preceded by a prepulse to $-40 \mathrm{mV}$. C, current density-voltage relationship with $100 \mathrm{nM}$ MANT-GTP $\gamma \mathrm{S}$ diluted in the pipette solution in the absence (filled symbols; $n=5$ ) and in the presence (open symbols; $n=5$ ) of $100 \mathrm{nM}(-$ )-isoproterenol measured at the beginning and at the end of the experiments, respectively. $*, p<0.05$ (alternate $t$ test). $\mathrm{D}$, maximal increase of L-type $\mathrm{Ca}^{2+}$ current density by isoproterenol (percentage of predrug values) compared with basal current in the absence (black bar; $n=10$ ) and in the presence of $100 \mathrm{nM}$ (gray bar; $n=5$ ) or $1 \mu \mathrm{M}$ (white bar; $n=11$ ) MANT-GTP $\gamma \mathrm{S}$, respectively. $*, p<0.05$ versus control (alternate $t$ test).

MANT-GTP $\gamma \mathrm{S}(+3 \pm 2 \%$; N.S. versus control), currents were unaffected; $1 \mu \mathrm{M}$ MANT-GTP $\gamma \mathrm{S}$ decreased current by already $-19 \pm 4 \%(p<0.01$ versus control; $n=5)$. This confirms that lower concentrations of MANT-GTP $\gamma$ S did not affect basal $\mathrm{I}_{\mathrm{Ca}, \mathrm{L}}$. In summary, basal and isoproterenol-stimulated inhibition of $\mathrm{I}_{\mathrm{Ca}, \mathrm{L}}$ in the presence of MANT-GTP $\gamma \mathrm{S}$ is concentration-dependent.

Effect of MANT-GTP $\gamma \mathbf{S}$ on Basal $\mathrm{I}_{\mathrm{Ca}, \mathrm{L}}$ in $\mathrm{AC5}^{-/-}$Myocytes. To determine AC5-specific effects of MANT-nucleotides and to characterize the functional role of AC5, experiments obtained with WT cardiomyocytes were repeated in ventricular myocytes from mice lacking AC5 (AC5 ${ }^{-/-}$). In ventricular myocytes from $\mathrm{AC} 5^{-1-}$ mice, $1 \mu \mathrm{M}$ MANTGTP $\gamma \mathrm{S}$ decreased $\mathrm{I}_{\mathrm{Ca}, \mathrm{L}}$ (after $10 \mathrm{~min},-23 \pm 1$ versus $8 \pm 2 \%$ without MANT-GTP $\gamma \mathrm{S} ; p<0.01, n=6$; Fig. 6 , A and B). This reduction of basal $\mathrm{I}_{\mathrm{Ca}, \mathrm{L}}$ in AC5 ${ }^{-1-}$ myocytes was significantly less pronounced than in WT myocytes (after $10 \mathrm{~min},-41 \pm$ $7 \% ; p<0.05, n=6$ ), indicative for an AC5-specific effect of MANT-GTP $\gamma \mathrm{S}$.

Effects of MANT-GTP $\gamma \mathbf{S}$ on $\mathbf{I}_{\mathrm{Ca}, \mathrm{L}}$ Stimulation by Isoproterenol in AC5 $^{-/-}$Myocytes. In accordance with previous findings (Okumura et al., 2003a) isoproterenol effects on $\mathrm{I}_{\mathrm{Ca}, \mathrm{L}}$ were mitigated in ventricular myocytes of $\mathrm{AC5} 5^{-/-}$ mice. It is noteworthy that MANT-GTP $\gamma \mathrm{S}$ at $1 \mu \mathrm{M}$ did not further attenuate $\mathrm{I}_{\mathrm{Ca}, \mathrm{L}}$ stimulated by isoproterenol in AC5 $^{-1-}$ myocytes (32 \pm 3 versus $29 \pm 3 \%$; N.S., $n=5$; Fig. 7 , A-C). Toward the end of incubation, isoproterenol effects seemed to decrease in the presence of MANT-GTP $\gamma \mathrm{S}$. How- 
A $\quad \mathrm{AC5}^{-/-}$
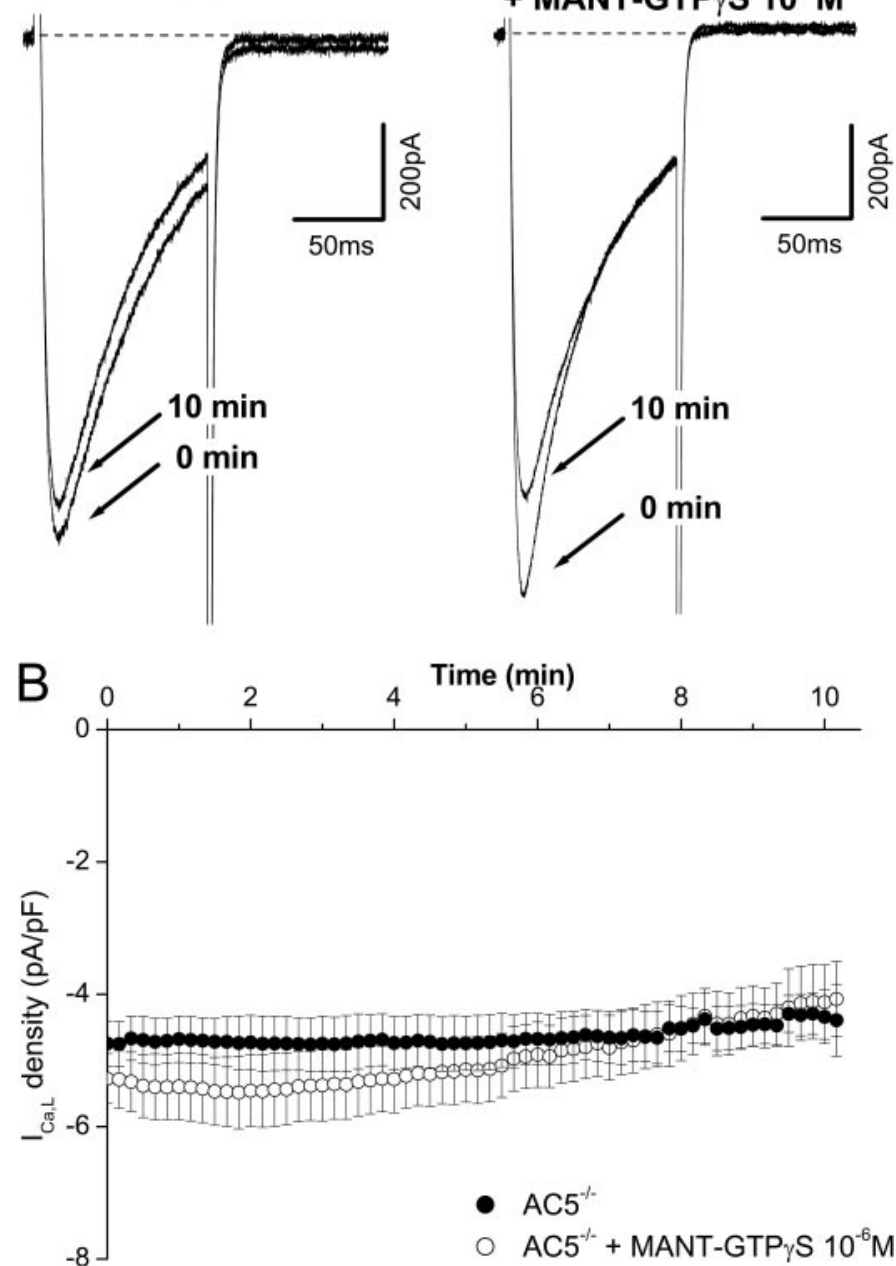

Fig. 6. Effect of $1 \mu \mathrm{M}$ MANT-GTP $\gamma \mathrm{S}$ on basal L-type $\mathrm{Ca}^{2+}$ current in $\mathrm{AC5}^{-1-}$ murine cardiomyocytes. A, original traces in the absence and presence of $1 \mu \mathrm{M}$ MANT-GTP $\gamma \mathrm{S}$ at the time points 0 and $10 \mathrm{~min}$. B, averaged time course of whole-cell L-type $\mathrm{Ca}^{2+}$ current density from experiments with murine ventricular myocytes lacking type $5 \mathrm{AC}$ $\left(\mathrm{AC5}^{-1-}\right)$ in the absence (filled symbols; $n=6$ ) and in the presence of 1 $\mu \mathrm{M}$ MANT-GTP $\gamma \mathrm{S}$ (open symbols; $n=6$ ). Starting from a holding potential of $-60 \mathrm{mV}$ the current was elicited by a test potential of $+10 \mathrm{mV}$ preceded by a prepulse to $-40 \mathrm{mV}$.

ever, subtraction of the basal $\mathrm{I}_{\mathrm{Ca}, \mathrm{L}}$ time course (cf. Fig. 6B) from isoproterenol-stimulated $\mathrm{I}_{\mathrm{Ca}, \mathrm{L}}$ revealed that this effect is entirely explained by the reduction in basal L-type $\mathrm{Ca}^{2+}$ current activity (data not shown). The MANT-GTP $\gamma \mathrm{S}$ resistance of isoproterenol effects in $\mathrm{AC}^{-/-}$myocytes was confirmed by nearly unaffected I/V curves (Fig. 7, D and E).

\section{Discussion}

In our present study, we characterized the effect of the novel competitive AC inhibitor MANT-GTP $\gamma \mathrm{S}$ on murine ventricular $\mathrm{I}_{\mathrm{Ca}, \mathrm{L}}$. MANT-GTP $\gamma \mathrm{S}$ is well suited for electrophysiological studies using intracellular dialysis because it is hydrolysis-resistant. Our findings indicate AC5 to be the major functional isoform mediating acute $\beta_{1}$-adrenergic stimulation of $\mathrm{I}_{\mathrm{Ca}, \mathrm{L}}$. In the presence of MANT-GTP $\gamma \mathrm{S}$, we find an attenuation of $\mathrm{I}_{\mathrm{Ca}, \mathrm{L}}$ increase following $\beta$-adrenergic stimulation via isoproterenol, confirming previous findings obtained with AC5-deficient mice (Okumura et al., 2003a). Most importantly, we found that in AC5-deficient mice, $1 \mu \mathrm{M}$ MANTGTP $\gamma \mathrm{S}$ did not further attenuate maximal $\mathrm{I}_{\mathrm{Ca}, \mathrm{L}}$ response to isoproterenol. Considering the similar affinities of MANTGTP $\gamma \mathrm{S}$ to the cardiac isoforms AC5 and AC6 (Gille et al., 2004), we conclude that AC5 plays a major role in mediating immediate $\beta$-adrenergic stimulation of L-type $\mathrm{Ca}^{2+}$ channels in ventricular cardiomyocytes.

Using the lower concentration of MANT-GTP $\gamma \mathrm{S}, 100 \mathrm{nM}$, a moderate inhibition of isoproterenol effects was obtained without concomitant inhibition of basal currents. Furthermore, $\mathrm{I}_{\mathrm{Ca}, \mathrm{L}}$ increase following isoproterenol was maintained here, whereas in the presence of $1 \mu \mathrm{M}$ nucleotide, $\mathrm{I}_{\mathrm{Ca}, \mathrm{L}}$ decreased continuously during the course of experiments. This indicates that the isoproterenol-stimulated current is more sensitive toward the AC inhibitor than the basal current. The only minimal effect of MANT-GTP $\gamma \mathrm{S}$ on basal current in AC5-deficient mice reveals that part of the inhibition of basal current in WT mice is due to AC5 inhibition. Additional mechanisms, such as involvement of a less sensitive functional AC isoform in basal current regulation, or other nonspecific effects of the nucleotide cannot be further elucidated by our experiments. Thus, our data reveal AC5 to activate tonically basal $\mathrm{Ca}^{2+}$ current activity. This interpretation might at first glance contrast to the unchanged basal current values reported for $\mathrm{AC} 5^{-1-}$ mice by group comparison (Okumura et al., 2003a), but long-term compensatory mechanisms are to be expected in such genetic models. Considering the lower isoproterenol effect on $\mathrm{I}_{\mathrm{Ca}, \mathrm{L}}$ in $\mathrm{AC} 5^{-/-}$myocytes, one might also speculate on decreased abundance of potential phosphorylation sites, e.g., by lower expression of the poreforming, protein kinase A-sensitive $\alpha 1 \mathrm{C}$ subunit coded by exon 1a (van der Heyden et al., 2005) or altered composition of the heteromeric channel complex by pore-forming $\alpha 1 \mathrm{C}$ and auxiliary $\beta$-subunits (Bünemann et al., 1999).

MANT-nucleotides represent novel experimental tools in the search for potential therapeutic compounds because they are competitive AC inhibitors (Gille and Seifert, 2003). Recent high-resolution crystallographic data underline their eminent role as lead compounds for the development of potent and isoform-specific AC inhibitors (Mou et al., 2005, 2006). Our present data show that isoproterenol effects are reduced by MANT-GTP $\gamma \mathrm{S}$ via concentration-dependent inhibition of AC5. Considering the sympathetic overdrive in heart failure, this indicates MANT-nucleotides as promising starting points regarding innovative therapeutic strategies. MANT-GTP $\gamma \mathrm{S}$ as a prototypical competitive AC inhibitor shows AC5-mediated effects, as proven by its lack of effect on isoproterenol-stimulation of $\mathrm{I}_{\mathrm{Ca}, \mathrm{L}}$ in $\mathrm{AC} 5^{-/-}$cardiomyocytes. Because AC5 deficiency seems to be protective against heart failure due to pressure overload (Okumura et al., 2003b), this demonstrates that MANT-nucleotides could serve as a novel approach in the therapy of cardiac diseases. This is supported by the known benefits of $\beta$-adrenoceptor antagonists in the treatment of heart failure. $\beta$-Adrenoceptor antagonists have become standard treatment of heart failure, although it is unclear what the exact underlying mechanism is. Some data suggest that signaling via $\beta_{2}$-adrenoceptors would be beneficial (Dorn et al., 1999; Du et al., 2000), whereas $\beta_{1}$ adrenoceptor signaling obviously is detrimental (Engelhardt et al., 1999; Lohse et al., 2003). This divergence is supported by findings on the differential signaling cascades and L-type 

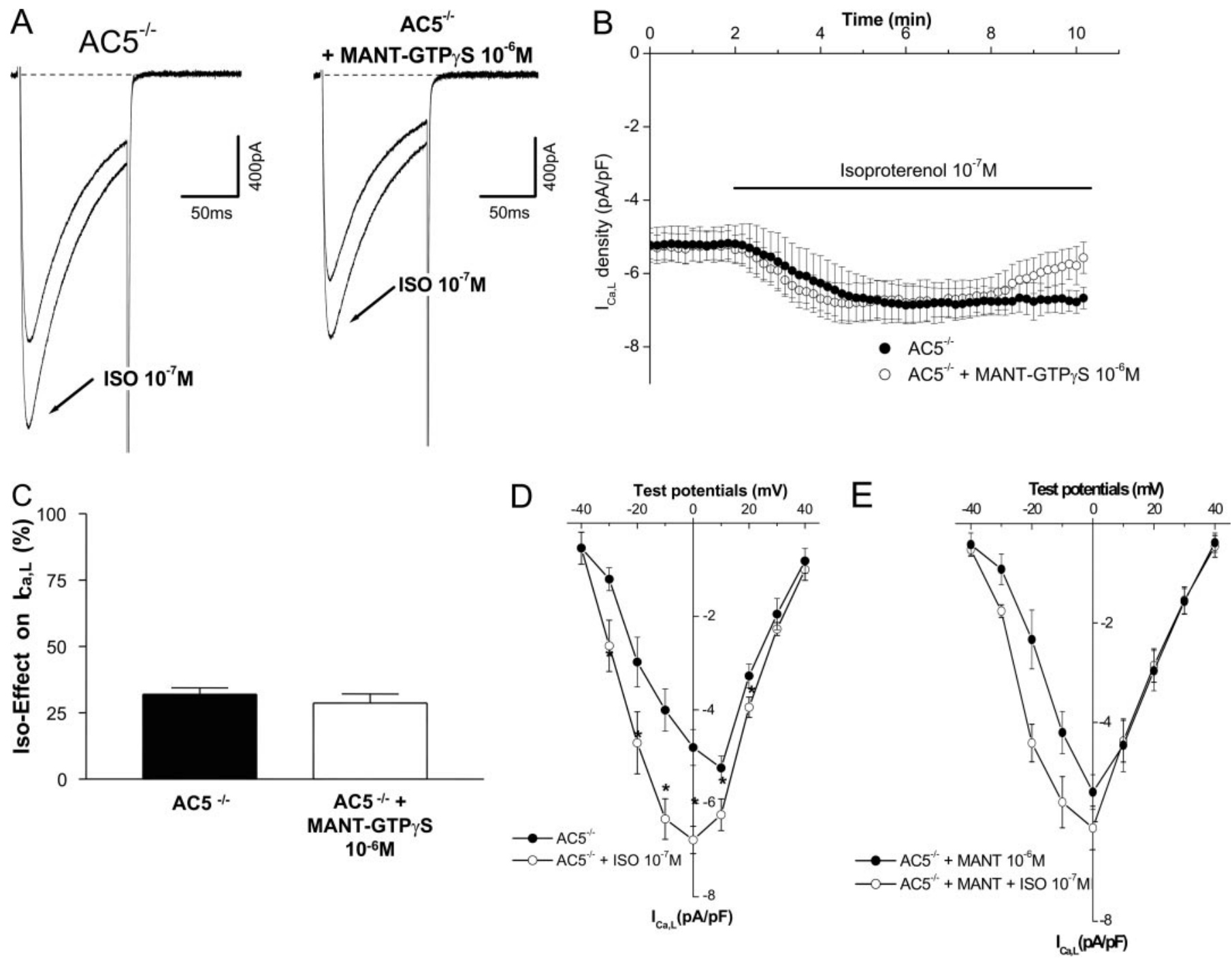

Fig. 7. Effect of $1 \mu \mathrm{M}$ MANT-GTP $\gamma \mathrm{S}$ on isoproterenol-stimulated L-type $\mathrm{Ca}^{2+}$ current in $\mathrm{AC}^{-1-}$ murine cardiomyocytes. Cells were superfused by isoproterenol containing bath solution for $8.2 \pm 0.1 \mathrm{~min}$ (control) and $8.2 \pm 0.1 \mathrm{~min}$ (MANT-GTP $\gamma \mathrm{S}$ ), respectively. A, original traces before and after $100 \mathrm{nM}(-)$-isoproterenol stimulation and in the absence and presence of $1 \mu \mathrm{M}$ MANT-GTP $\gamma \mathrm{S}$ at the time point 0 min and at the maximal increase of L-type $\mathrm{Ca}^{2+}$ current. B, averaged time course of whole-cell L-type $\mathrm{Ca}^{2+}$ current density from experiments with murine ventricular myocytes lacking type $5 \mathrm{AC}\left(\mathrm{AC}^{-1-}\right)$ before and after $100 \mathrm{nM}(-)$-isoproterenol stimulation and in the absence (filled symbols; $\left.n=5\right)$ and in the presence of $1 \mu \mathrm{M}$ MANT-GTP $\gamma \mathrm{S}$ (open symbols; $n=5$ ). Starting from a holding potential of $-60 \mathrm{mV}$, the current was elicited by a test potential of $+10 \mathrm{mV}$ preceded by a prepulse to $-40 \mathrm{mV}$. C, maximal increase of L-type $\mathrm{Ca}^{2+}$ current density (percentage) compared with basal current $(=0)$ in the absence (black bar; $n=5$ ) and in the presence (white bar; $n=5$ ) of $1 \mu \mathrm{M}$ MANT-GTP $\gamma \mathrm{S}$. D, control current density-voltage relationship from AC5 ${ }^{-1-}$ myocytes in the absence (filled symbols; $n=5$ ) and in the presence (open symbols; $n=5$ ) of $100 \mathrm{nM}(-$ )-isoproterenol measured at the beginning and at the end of the experiments. E, current density-voltage relationship from AC5 ${ }^{-1-}$ myocytes with $1 \mu \mathrm{M}$ MANT-GTP $\gamma \mathrm{S}$ diluted in the pipette solution in the absence (filled symbols; $n=5$ ) and in the presence (open symbols; $n=5$ ) of $100 \mathrm{nM}(-$ )-isoproterenol measured at the beginning and at the end of the experiments, respectively.

$\mathrm{Ca}^{2+}$ channel regulation by $\beta_{1^{-}}$and $\beta_{2^{-}}$-adrenoceptors (Foerster et al., 2003, 2004; Xiao et al., 2006). A major difference is dual signaling via $G_{i}$ and $G_{s}$ proteins by $\beta_{2}$-adrenoceptors, and only $\mathrm{G}_{\mathrm{s}}$ in case of $\beta_{1}$-adrenoceptors. Hence, adenylyl cyclase inhibitors might be an attractive alternative to $\beta$-adrenoceptor antagonists due to their selective prevention of an (excessive) increase of cAMP.

In future studies, we will have to design potent cell-permeable AC5 inhibitors because the currently available AC inhibitors are not cell membrane-permeable. A feasible approach is the design of pronucleotides that can be deprotected and phosphorylated within cells (Laux et al., 2004). Moreover, we have already shown that MANT-nucleoside $5^{\prime}$ diphosphates are phosphorylated to the corresponding triphos- phates by cellular kinases (Gille et al., 2004). It should be emphasized that the concept of AC5 inhibition for the treatment of cardiovascular disease is quite different from the current concept of $\beta_{1}$-adrenoceptor blockade because ACs integrate the input from multiple receptor systems (Hanoune and Defer, 2001). Our present study shows that the combination of pharmacological studies with gene knockout studies is very powerful at delineating signal transduction pathways and establishing novel therapeutic concepts.

\section{Acknowledgments}

We thank Dr. Andreas Gille (University of Heidelberg, Heidelberg, Germany) for helpful discussions and Sigrid Kirchmann and Jens Reifenrath for skillful technical support. 


\section{References}

Bünemann M, Gerhardstein BL, Gao T, and Hosey M (1999) Functional regulation of L-type calcium channels via protein kinase A-mediated phosphorylation of the $\beta_{2}$-subunit. J Biol Chem 274:33851-33854.

Defer N, Best-Belpomme M, and Hanoune J (2000) Tissue specificity and physiological relevance of various isoforms of adenylyl cyclase. Am J Physiol 279:F400F416.

Dorn GW 2nd, Tepe NM, Lorenz JN, Koch WJ, and Liggett SB (1999) Low- and high-level transgenic expression of $\beta_{2}$-adrenergic receptors differentially affect cardiac hypertrophy and function in $\mathrm{G}_{\mathrm{q}}$-overexpressing mice. Proc Natl Acad Sci USA 96:6400-6405.

Du XJ, Gao XM, Jennings GL, Dart AM, and Woodcock EA (2000) Preserved ventricular contractility in infarcted mouse heart overexpressing $\beta_{2}$-adrenergic receptors. Am J Physiol 279:H2456-H2463.

Engelhardt S, Hein L, Wiesmann F, and Lohse MJ (1999) Progressive hypertrophy and heart failure in beta1-adrenergic receptor transgenic mice. Proc Natl Acad Sci USA 96:7059-7064.

Foerster K, Groner F, Matthes J, Koch WJ, Birnbaumer L, and Herzig S (2003) Cardioprotection specific for the $G$ protein $G_{i 2}$ in chronic adrenergic signaling through $\beta_{2}$-adrenoceptors. Proc Natl Acad Sci USA 100:14475-14480.

Foerster K, Kaeferstein T, Groner F, Engelhardt S, Matthes J, Koch WJ, Lohse MJ, and Herzig $S$ (2004) Calcium channel function and regulation in $\beta_{1^{-}}$and $\beta_{2}$ adrenoceptor transgenic mice. Naunyn-Schmiedeberg's Arch Pharmacol 369:490495.

Gao MH, Lai NC, Roth DM, Zhou J, Anzai T, Dalton N, and Hammond HK (1999) Adenylylcyclase increases responsiveness to catecholamine stimulation in transgenic mice. Circulation 99:1618-1622.

Gille A, Lushington GH, Mou T-C, Doughty MB, Johnson RA, and Seifert R (2004) Differential inhibition of adenylyl cyclase isoforms and soluble guanylyl cyclase by purine and pyrimidine nucleotides. J Biol Chem 279:19955-19969.

Gille A and Seifert R (2003) 2'(3')-O-(N-Methylanthraniloyl)-substituted GTP analogs: a novel class of potent competitive adenylyl cyclase inhibitors. $J$ Biol Chem 278:12672-12679.

Hanoune J and Defer N (2001) Regulation and role of adenylyl cyclase isoforms. Annu Rev Pharmacol Toxicol 41:145-174.

Heubach JF, Graf EM, Molenaar P, Jager A, Schroder F, Herzig S, Harding SE, and Ravens U (2001) Murine ventricular L-type $\mathrm{Ca}^{2+}$ current is enhanced by zinterol via $\beta_{1}$-adrenoceptors, and is reduced in TG4 mice overexpressing the human $\beta_{2}$-adrenoceptor. $\mathrm{Br}$ J Pharmacol 133:73-82.

Ishikawa Y, Katsushika S, Chen L, Nalhon NJ, Kawabe J, and Homcy CJ (1992)
Isolation and characterization of a novel cardiac adenylylcyclase cDNA. $J$ Biol Chem 267:13553-13557.

Iwatsubo K, Minamisawa S, Tsunematsu T, Nakagome M, Toya Y, Tomlinson JE, Umemura S, Scarborough RM, Levy DE, and Ishikawa Y (2004) Direct inhibition of type 5 adenylyl cyclase prevents myocardial apoptosis without functional deterioration. J Biol Chem 279:40938-40945.

Kamp TJ and Hell JW (2000) Regulation of cardiac L-type calcium channels by protein kinase A and protein kinase C. Circ Res 87:1095-1102.

Laux WH, Pande P, Shoshani I, Gao J, Boudou-Vivet V, Gosselin G, and Johnson RA (2004) Pro-nucleotide inhibitors of adenylyl cyclases in intact cells. J Biol Chem 279:13317-13332.

Lohse MJ, Engelhardt S, and Eschenhagen T (2003) What is the role of $\beta$-adrenergic signaling in heart failure? Circ Res 93:896-906.

Mou T-C, Gille A, Fancy DA, Seifert R, and Sprang RA (2005) Structural basis for the inhibition of mammalian membrane adenylyl cyclase by $2^{\prime}\left(3^{\prime}\right)-O$ - $(N$-methylanthraniloyl)-guanosine 5-triphosphate. J Biol Chem 280:7253-7261.

Mou TC, Gille A, Suryanarayana S, Richter M, Seifert R, and Sprang SR (2006 Broad specificity of mammalian adenylyl cyclase for interaction with $2^{\prime}, 3^{\prime}$ substituted purine- and pyrimidine nucleotide inhibitors. Mol Pharmacol 70:878886.

Okumura S, Kawabe J, Yatani A, Takagi G, Lee MC, Hong C, Liu J, Takagi I, Sadoshima J, Vatner DE, et al. (2003a) Type 5 adenylyl cyclase disruption alters not only sympathetic but also parasympathetic and calcium-mediated cardiac regulation. Circ Res 93:364-371.

Okumura S, Takagi G, Kawabe J, Yang G, Lee MC, Hong C, Liu J, Vatner DE, Sadoshima J, Vatner SF, et al. (2003b) Disruption of type 5 adenylyl cyclase gene preserves cardiac function against pressure overload. Proc Natl Acad Sci USA 100:9986-9990.

Tepe NM, Lorenz JN, Yatani A, Dash R, Krania EG, Dorn GW, and Liggett SB (1999) Altering the receptor-effector ratio by transgenic overexpression of type $\mathrm{V}$ adenyly cyclase: enhanced basal catalytic activity and function without increased cardiomyocyte $\beta$-adrenergic signaling. Biochemistry 38:16706-16713.

van der Heyden MAG, Wijnhoven TJM, and Opthof T (2005) Molecular aspects of adrenergic modulation of cardiac L-type $\mathrm{Ca}^{2+}$ channels. Cardiovasc Res 65:28-39.

Xiao RP, Zhu W, Zheng M, Cao C, Zhang Y, Lakatta EG, and Han Q (2006) Subtype-specific $\alpha_{1}$ - and $\beta$-adrenoceptor signaling in the heart. Trends Pharmaco Sci 27:330-337.

Address correspondence to: Dr. Stefan Herzig, Department of Pharmacology, University of Cologne, Gleueler Str. 24, D-50931 Köln, Germany. E-mail: stefan.herzig@uni-koeln.de 